\section{Sources of variation in energy and nutrient intakes among children from six to thirty months old in a population-based study}

\author{
Fontes de variação no consumo de energia e \\ nutrientes entre crianças de seis a trinta meses \\ de um estudo de base populacional
}

\author{
${ }^{1}$ Instituto de Nutrição Josué \\ de Castro, Universidade \\ Federal do Rio de Janeiro, \\ Rio de Janeiro, Brasil. \\ 2 Centro de Ciências Médicas, \\ Universidade Federal \\ Fluminense, Niterói, Brasil. \\ Correspondence \\ R. Salles-Costa \\ Instituto de Nutrição Josué de \\ Castro, Universidade Federal \\ do Rio de Janeiro. \\ Av. Carlos Chagas Filho 373, \\ CCS, Bloco J, 2o andar, Rio de \\ Janeiro, $R J$ \\ 21941-902, Brasil. \\ rosana@nutricao.ufrj.br
}

Abstract

The objective of this article was to describe and analyze sources of variation in the dietary intakes of children aged 6 to 30 months. The data was obtained from two 24-hour recall surveys of a sample of 383 children of both sexes in the metropolitan region of Rio de Janeiro, Brazil. Age and the food insecurity scale, which was used as a proxy to characterize socioeconomic differences, were considered. The analysis was based on food groups. The ratio of the coefficients' variation was calculated, and the crude and de-attenuated relative means for energy and macro- and micronutrients were estimated. In addition, the number of 24-hour recall replications was also estimated. Age and food insecurity had significant impacts on the average number of servings offood groups. The coefficients of variation ratios for most nutrients were $<1$, except for vitamin $C$ and for children in the younger age group. The number of 24-hour recall required ranged from 1 to 6 days and was higher for vitamin $C$.

Food Consumption; Diet Surveys; Child
Rosana Salles-Costa 1

Gabriela dos Santos Barroso 1

Melissa Arêas de Mello 1

Marina Maria Leite Antunes 1

Edna Massae Yokoo ${ }^{2}$

\section{Introduction}

Gathering and assessing information on the food intake of a population or population groups is a key strategy for nutrition and health research. This information supports the establishment of public policies to improve the population's health and agricultural planning for the country. Based on dietary intake assessment, it is possible to estimate more accurately the amount of energy a population intakes or whether a particular nutrient may be interfering with the health of a population 1 .

The most common dietary assessment methods are Food Frequency Questionnaire (FFQ), 24-hour dietary recall, food records, and dietary history. FFQ and diet histories are based on the report of habitual food intake, and these are generally used to obtain information over a longer period of time, usually months or years. Food records and 24-hour recalls are based on foods and amounts that are actually consumed by an individual on one or more specific days 2 .

Accurate and precise assessment of the usual dietary intake remains a major challenge in studies of the relationship between diet and disease. Beaton et al. ${ }^{3}$ published the results of an analysis of sources of variance in 24-hour dietary recall data and emphasized that there is no ideal dietary method.

Dietary intake is affected by daily, weekly, and seasonal variations, and it tends to change over 
the years 4 . Therefore, to estimate associations between diet and health, it is necessary to estimate individuals' usual intakes with instruments for dietary assessment that are able to gather the wide variability observed in individual and group intake 5 .

Measuring an individual's true intake is difficult due to measurement and random errors in dietary assessment. Random errors in food intake arise because each individual differs in the types and amounts of food consumed from one day to the next (within-subject variability) and also because individuals differ from each other in their food intakes (between-subject variability) 4,6.

The estimated consumption of energy and nutrients in infancy is particularly challenging due to the higher number of errors in measuring diet, which compromises the accuracy of methods for assessing food intake in this age group 1 . The reliance on parents is one of the factors that contribute to the reduction of accuracy in the measurement of food intake in children; usually the child's mother is called on to report the foods and preparations consumed by them ${ }^{7}$.

In adult populations, dietary intake and variance estimates depend on gender, age, day of the week or season, socioeconomic factors and culture ${ }^{3}$. Among children, it is also expected that some sources of variation may affect the usual dietary intake. Therefore, some random error might occur and could attenuate the association between dietary intake and disease. Nelson et al. 8 revealed important differences in variances for nutrients between different age groups and genders. In addition, Jahns et al. 9 showed important variance differences between Russian and American children.

Although different studies have characterized within- and between-person variance for energy and nutrient intakes in adults 10,11 very little information is available for children 12,13 , especially in Brazil. In addition, most studies of the child population are usually held in public health institutions and at nursery schools 14,15,16,17,18 and few population-based studies have been conducted in recent years 19,20,21,22.

Nutritional intake is increasingly seen as an important environmental factor affecting health and development in early life, thus focusing attention on accurate methods to estimate usual nutrient intakes in the early stage of life. Such methods are essential for research that aims to analyze the burden of dietary intake during early life and disease. This study aimed to contribute to this issue by identifying some potential sources of within-subject variability that may affect random errors and would attenuate any disease association with energy and nutrient intake in infants and very young children in a populationbased sample.

\section{Subjects and methods}

Data used for these analyses are from a population-based cross-sectional study with a representative sample in Duque de Caxias, a city in the metropolitan area of Rio de Janeiro, Brazil. Using a multistage cluster sampling procedure and considering $14.5 \%$ of poverty in this population, a sample size of 1,125 households was estimated. Data were collected in 1,085 households, thus with $3.4 \%$ missing. Specifically for children from 6 to 30 months old from 435 sampled households, 402 had data collected, with $7.6 \%$ missing. In this paper 383 children that had two days of food intake available were studied ( $4.7 \%$ missing). More details regarding sample design have been described previously by Salles-Costa et al. 23 .

This study was approved by the Institutional Review Board of the Social Medicine Institute, Rio de Janeiro State University and participants signed informed consent forms. A questionnaire was used to evaluate socio-demographic characteristics and applied by 16 interviewers. Two 24-hour recalls were used on non-consecutive days that were chosen randomly between two weeks and one month. Due to the children's ages, a proxy, an adult who usually spent most of the time with the child (generally the mother), was used to obtain dietary intake information. The data were collected in face-to-face interviews administered by six trained nutritionists from May to December 2005. Recommendations about portion size, plates, spoons, and bottle were given to the proxy to mitigate information bias. The interviewers attended three training sessions about measuring procedures for the questionnaire and food intake methods.

\section{Data analysis}

The socio-demographic characteristics of the study group were available by questionnaire and described using the following variables: per capita income, proxy reference educational level, household family size, food insecurity (estimated by Brazilian Food Insecurity Scale - EBIA 24) and skin color/race (evaluated by interview in accordance with the Brazilian Institute of Geography and Statistics; IBGE) 25.

The variables were presented as prevalence (\%) with 95\% confidence intervals (95\%CI).

Analyses by food group were based on the eight groups proposed by the Brazilian Ministry of Health 26: cereals, vegetables, fruits, dairy prod- 
ucts, meats (meat, chicken and fish) and eggs, beans, fats (soy oil, butter) and sweets. Portion size weights (in grams) were estimated for each food group as recommended by Philippi et al. 27 .

Food groups were analyzed by two age groups (6-17 months and 18-30 months of age) that were each stratified by groups of socioeconomic marker variables, characterized in this study according to the EBIA (group 1: food security and mild food insecurity; group 2: moderate and severe food insecurity) ${ }^{28}$. The validity of the adapted U.S. Household Food Security Supplemental Module (HFSSM) in Brazil has been analyzed in research that replicated the methodology in several urban and/or rural areas throughout the country. This resulted in a recommendation to use the proposed instrument in a representative survey sample, which made it possible to estimate the prevalence of food security at the national level 29.

Dietary intakes of energy, carbohydrates, protein, lipids, calcium, iron, and vitamin $\mathrm{C}$ were estimated using the software program NutWin Programa de Apoio à Nutrição (Departamento de Informática em Saúde, Universidade de São Paulo, Brasil), which is based on the United States Department of Agriculture (USDA) database. For items that were not included in the NutWin software food composition table, the centesimal composition was obtained from the Brazilian Food Composition Table (TACO, versão 1. Núcleo de Estudos e Pesquisas em Alimentação, Universidade Estadual de Campinas, Campinas, Brasil; $5 \%$ of foods analyzed). Standard recipes and serving sizes were used to estimate the nutritional composition of preparations that were not included in the software database.

The within- and between-subject variances were estimated, based on the two 24-hour recall means, considering ages and food security groups. The consumption of energy and nutrients was de-attenuated using the methodology proposed by Iowa State University and the software C-Side (Iowa State University; http://www. cssm.iastate.edu/software/cside.html), which examined the distribution of each nutrient and performed the appropriate transformations for the ones with skewed distributions. The de-attenuation was based on the first day of 24-hour recall. The variance ratio of within-subject/between-subject was calculated, and the means of the crude and de-attenuated consumptions of nutrients were estimated for all groups.

To estimate the number of 24 -hour recall replications required to estimate the usual intake of the children, we adopted the procedures proposed by Palaniappan et al. ${ }^{4}$ and Nelson et al. 8 , which estimates the number of replications of 24-hour recalls based on the expected correlation coefficient between the observed and actual intakes (equation 1).

$$
\left.\mathrm{d}=\left(\frac{\mathrm{r}^{2}}{1-\mathrm{r}^{2}}\right) \frac{\mathrm{s}_{\mathrm{w}}^{2}}{\mathrm{~s}_{\mathrm{b}}^{2}} \quad \text { (equation } 1\right)
$$

Where, $d$ is the number of replications required; $r$ is the expected correlation coefficient between observed and true intakes (in this study, estimations were calculated for 0.9); and $\frac{\mathrm{s}_{\mathrm{w}}^{2}}{2}$ is the within/between-subject variance ratio.

An analysis of household socio-demographic characteristics was carried out, taking into account the effect of the sampling study design, thus estimated parameters were expanded for the study population. Data analysis specifically for food intake of children from six to thirty months old did not consider the effect of the sampling design. The t-test was used to evaluate mean differences with $\mathrm{p}$-value less than 0.05. All procedures were analyzed by Stata software version 11.0 (Stata Corp., College Station, U.S.A.).

\section{Results}

The characteristics of the study population are presented in Table 1. Most households had some food insecurity (78\%) and incomes less than R\$ $200(77 \%)$. The reference person in the family (mother or father) had less than 10 years of education $(78.5 \%)$, and $71.6 \%$ self-referred as black or mulatto.

Age and food insecurity based on two 24-hour recalls had significant effects on the mean of food group servings (Figure 1). Children between 6 and 17 months old showed lower intakes of cereals ( $\mathrm{p}<0.001)$, fruits $(\mathrm{p}<0.0001)$, meats and eggs ( $\mathrm{p}<0.001)$, fats $(\mathrm{p}<0.001)$ and dairy products $(\mathrm{p}<0.0001)$ than children 18 months old or more (Figure 1a). According to food insecurity, children 6 to 17 months old with moderate to severe food insecurity (Figure 1b) reported lower intake of fat groups than children that were food secure or faced with mild insecurity $(p<0.05)$. On the other hand, children older than 18 months with food insecurity had significantly lower intakes of cereals, fruits, meat and eggs, sweets and dairy products $(\mathrm{p}<0.05)$ than other children of the same age with food security or mild food insecurity (Figure 1c).

Ratios of within- to between-subject variances were less than 1 for energy and nutrients for the most studied groups. However, vitamin C variance ratios were more than 1 (> 1 ; 1.16-1.29) for the youngest children. Overall, calcium in- 
Sample household socio-demographic characteristics. Duque de Caxias, Rio de Janeiro, Brazil, 2005.

\begin{tabular}{|c|c|c|}
\hline Socio-demographic characteristics & $\%$ * & $95 \% \mathrm{Cl}$ \\
\hline \multicolumn{3}{|l|}{ Food insecurity } \\
\hline Food security & 28.0 & 21.9-34.7 \\
\hline Mild food insecurity & 39.0 & $32.4-45.0$ \\
\hline Moderate food insecurity & 21.0 & $16.4-26.3$ \\
\hline Severe food insecurity & 12.0 & $7.4-15.6$ \\
\hline \multicolumn{3}{|l|}{ Family per capita income (quartiles) } \\
\hline$<\mathrm{R} \$ 50$ & 24.5 & 18.2-30.7 \\
\hline $\mathrm{R} \$ 50.10-\mathrm{R} \$ 105.00$ & 23.5 & $17.7-29.4$ \\
\hline$R \$ 105.10-R \$ 200.00$ & 29.0 & $22.2-35.3$ \\
\hline$>\mathrm{R} \$ 200.00$ & 23.0 & $16.3-29.8$ \\
\hline \multicolumn{3}{|c|}{ Educational level of reference person in the family (years) ** } \\
\hline Illiterate & 3.1 & $1.4-4.9$ \\
\hline$<8$ & 51.5 & $42.9-60.0$ \\
\hline $8-10$ & 23.9 & $18.8-28.9$ \\
\hline $11-14$ years & 20.9 & $14.5-27.3$ \\
\hline$\geq 15$ years & 0.4 & $0.1-10.0$ \\
\hline \multicolumn{3}{|l|}{ Number of person in household } \\
\hline $1-4$ & 51.3 & $45.9-56.8$ \\
\hline $5-8$ & 40.8 & $35.0-46.6$ \\
\hline$\geq 8$ & 7.7 & $4.0-11.4$ \\
\hline \multicolumn{3}{|c|}{ Skin color/race of reference person on the family ** } \\
\hline White & 28.4 & $22.5-34.3$ \\
\hline Black/Mulatto & 71.6 & $65.6-77.4$ \\
\hline
\end{tabular}

* Weighted proportions;

** Reference person for the family considered the mother or father of the child.

Figure 1

Mean number of food group servings by age and by food insecurity. Duque de Caxias, Rio de Janeiro, Brazil, 2005.

1a) All children

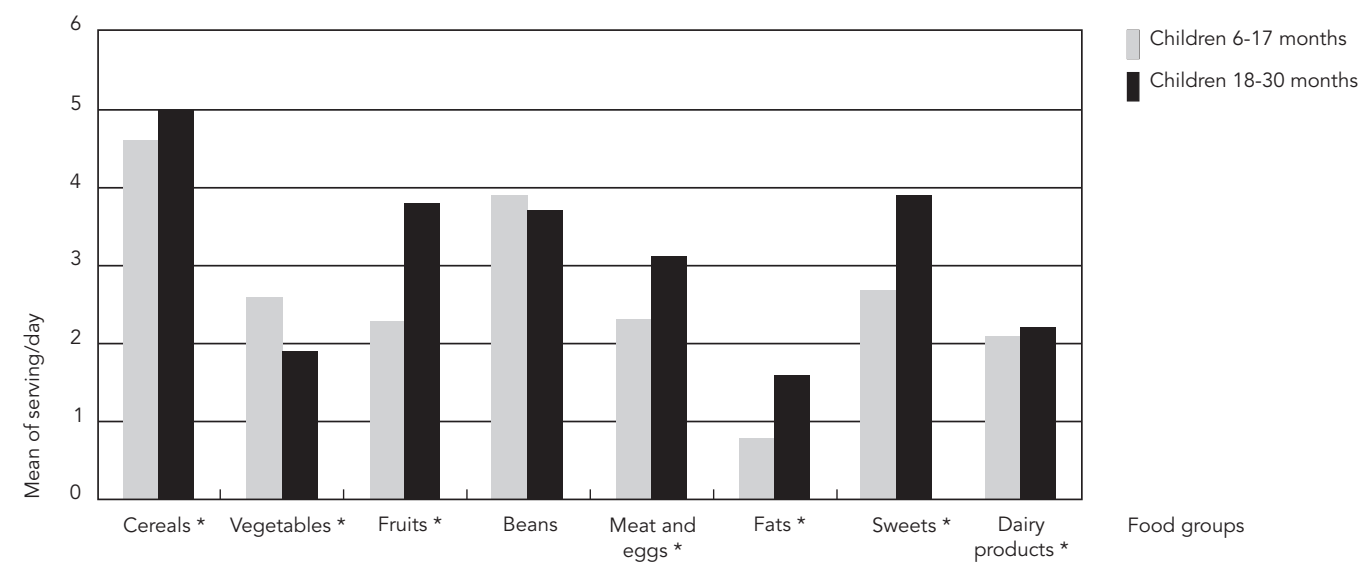

(continues) 
1b) Children 6-17 months old by food insecurity

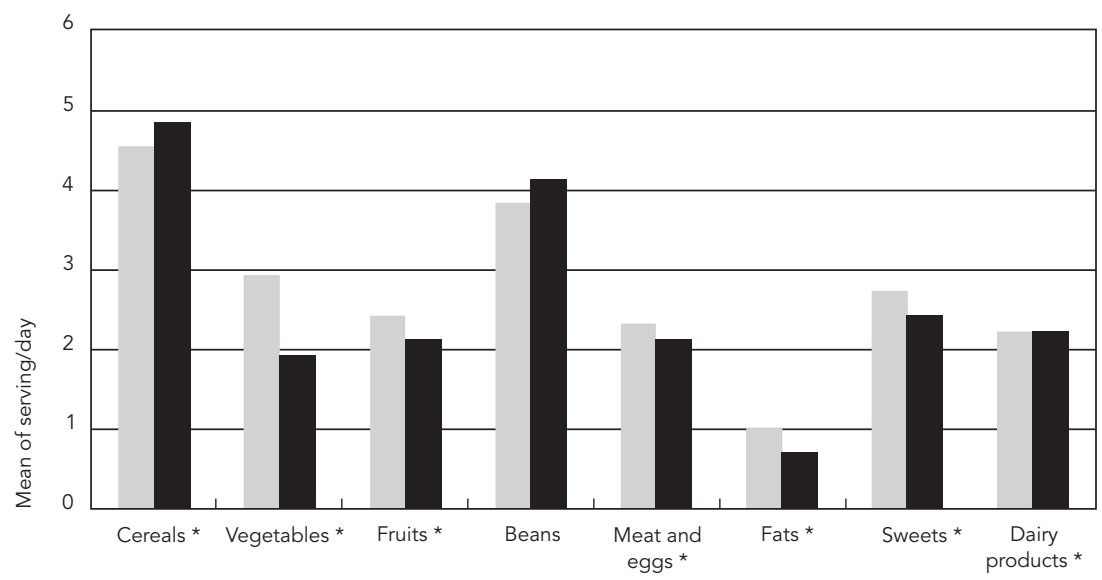

1c) Children 18-30 months old by food insecurity

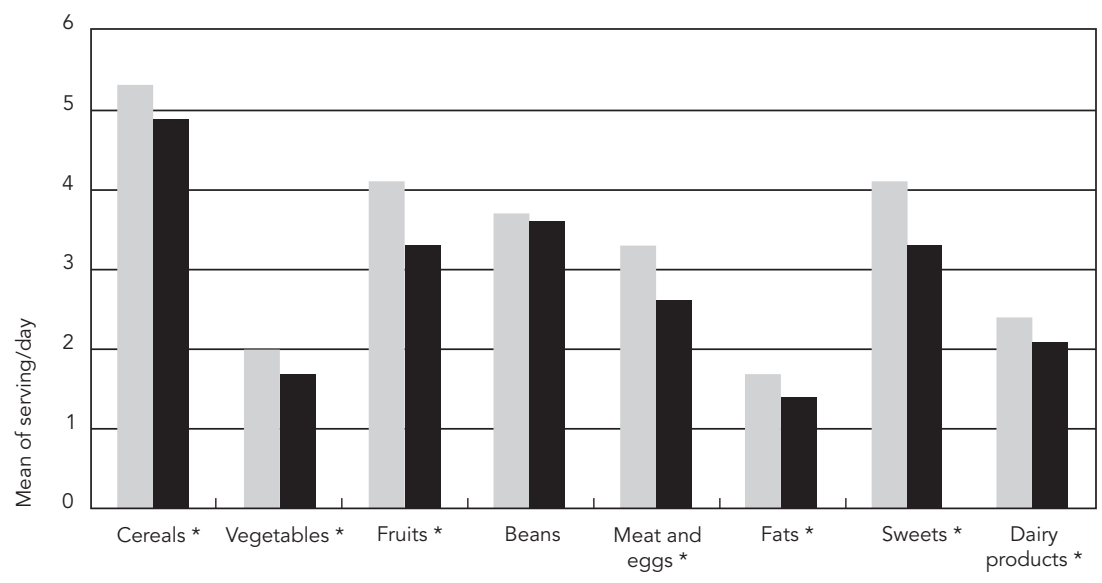

$\prod$ Food security + mild food insecurity

Moderate food insecurity + severe $\amalg$ Food security + mild food insecurity

Moderate + severe food insecurity

* t-student, p-value $<0.05$

takes presented lower variance ratios (0.18-0.54) than energy and other nutrient intakes. Variance ratios were slightly higher for the groups with moderate to severe food insecurity than they were for the group with food security; this was mainly for the protein (1.01) and carbohydrate (1.08) for the young and old age groups, respectively (Table 2).

For those 6 to 17 months old, the de-attenuated means of nutrient intakes tended to remain unchanged, with a reduction of the standard er- ror of the mean, except for vitamin $\mathrm{C}$, which did have a mean reduction. Those 18 months and older showed the same results, although iron and vitamin $\mathrm{C}$ had high means after de-attenuation in this group. Considering the socioeconomic marker groups, children with moderate to severe food insecurity at all ages had changes in the mean intake after de-attenuation. These were mainly for vitamin $\mathrm{C}$ in the older age group, which was reduced in the food security group and increased in the group with moderate to severe food 
Table 2

Variance ratio * for energy and nutrient intakes of children by age and food insecurity. Duque de Caxias, Rio de Janeiro, Brazil, 2005.

\begin{tabular}{|c|c|c|c|c|c|c|}
\hline \multirow[t]{2}{*}{ Nutrient intake } & \multicolumn{3}{|c|}{ Children 6-17 months } & \multicolumn{3}{|c|}{ Children $18-30$ months } \\
\hline & Total & $\begin{array}{l}\text { Food security + } \\
\text { mild food } \\
\text { insecurity }\end{array}$ & $\begin{array}{c}\text { Moderate + } \\
\text { severe food } \\
\text { insecurity }\end{array}$ & Total & $\begin{array}{l}\text { Food security + } \\
\text { mild food } \\
\text { insecurity }\end{array}$ & $\begin{array}{c}\text { Moderate + } \\
\text { severe food } \\
\text { insecurity }\end{array}$ \\
\hline Energy (kcal) & 0.51 & 0.35 & 0.79 & 0.54 & 0.52 & 0.96 \\
\hline Protein (g) & 0.69 & 0.59 & 1.01 & 0.71 & 0.86 & 0.78 \\
\hline Carbohydrate (g) & 0.59 & 0.41 & 0.82 & 0.55 & 0.48 & 1.08 \\
\hline Total fat (g) & 0.68 & 0.57 & 0.90 & 0.78 & 0.96 & 0.69 \\
\hline Calcium (mg) & 0.35 & 0.18 & 0.54 & 0.28 & 0.25 & 0.32 \\
\hline Iron (mg) & 0.60 & 0.46 & 0.79 & 0.75 & 0.88 & 0.76 \\
\hline Vitamin C (mg) & 1.16 & 1.29 & 1.08 & 0.82 & 0.88 & 0.92 \\
\hline
\end{tabular}

* Variance ratios of within- and between-person variances were expressed as $\mathrm{S}_{\mathrm{w}} / \mathrm{S}^{2} \mathrm{~b}$.

Table 3

Mean of crude and de-attenuated intakes of energy and nutrients and the number of days required to ensure $r \geq 0.9$ for children 6-17 months old and 18-30 months old by food insecurity. Duque de Caxias, Rio de Janeiro, Brazil, 2005.

\begin{tabular}{|c|c|c|c|c|c|c|c|c|}
\hline \multirow[t]{2}{*}{ Energy/Nutrients } & \multicolumn{4}{|c|}{ Children 6-17 months } & \multicolumn{4}{|c|}{ Children $18-30$ months } \\
\hline & $\begin{array}{c}\text { 1st } 24 \text { hour } \\
\text { recall }\end{array}$ & Mean & De-attenuated & Days & $\begin{array}{c}\text { 1st } 24 \text { hour } \\
\text { recall }\end{array}$ & Mean & De-attenuated & Days \\
\hline & \multicolumn{4}{|c|}{ Total $(n=154)$} & \multicolumn{4}{|c|}{ Total $(n=229)$} \\
\hline Energy (kcal/day) & $888(33)$ & $855(22)$ & $888(26)$ & 2 & $1,148(27)$ & $1,129(20)$ & $1,148(22)$ & 2 \\
\hline Carbohydrates (g/day) & $138(5.5)$ & $134(3.6)$ & $138.5(4.2)$ & 3 & $172(4.4)$ & $168(3.1)$ & $172(3.5)$ & 3 \\
\hline Protein (g/day) & $34(1.7)$ & $32(1)$ & $33.6(1.2)$ & 3 & $45(1.4)$ & $44(1)$ & $45(1)$ & 2 \\
\hline Lipids (g/day) & $23(0.9)$ & $22(0.6)$ & $22.9(0.7)$ & 3 & $32(0.9)$ & $32(0.7)$ & $32(0.7)$ & 3 \\
\hline Calcium (mg/day) & $577.1(32.4)$ & $562.0(22.9)$ & $576.9(28.0)$ & 1 & $659.8(22.9)$ & $649.4(16.8)$ & $659.8(20.1)$ & 1 \\
\hline Iron (mg/day) & $6.4(0.3)$ & $6.2(0.2)$ & $6.4(0.2)$ & 3 & $10.7(1.2)$ & $10.1(0.8)$ & $11.0(1.6)$ & 3 \\
\hline \multirow[t]{2}{*}{ Vitamin C (mg/day) } & $62.3(10.0)$ & $57.8(5.5)$ & $58.8(3.1)$ & 5 & $124.9(37.7)$ & $108.8(21.9)$ & $167.4(59.9)$ & 3 \\
\hline & \multicolumn{4}{|c|}{ Food security + mild food insecurity $(n=91)$} & \multicolumn{4}{|c|}{ Food security + mild food insecurity $(n=154)$} \\
\hline Energy (kcal/day) & $930(43)$ & $882(36)$ & $930(36)$ & 1 & $1,223(34.2)$ & $1,203(24.9)$ & $1,223(27)$ & 2 \\
\hline Carbohydrates (g/day) & $143(7)$ & $135(5.8)$ & $143(5.6)$ & 3 & $182(5.4)$ & $178(3.9)$ & $176(1.7)$ & 4 \\
\hline Protein (g/day) & $36(2.1)$ & $34(1.7)$ & $34(1.6)$ & 2 & $49(1.8)$ & $48(1.2)$ & $49(1.3)$ & 2 \\
\hline Lipids (g/day) & $25(1.3)$ & $23(1.1)$ & $21(0.6)$ & 2 & $34(1.2)$ & $34(0.9)$ & $34(0.8)$ & 4 \\
\hline Calcium (mg/day) & $588.2(41.0)$ & $570.2(38.2)$ & $588.8(37.4)$ & 1 & $693.9(28.0)$ & $679.1(20.3)$ & $694.0(25.1)$ & 1 \\
\hline Iron (mg/day) & $6.8(0.42)$ & $6.4(0.37)$ & $6.4(0.3)$ & 2 & $12.6(1.7)$ & $11.4(1.1)$ & $13.8(2.9)$ & 4 \\
\hline \multirow[t]{2}{*}{ Vitamin C (mg/day) } & $57.17(6.12)$ & $57.57(5.09)$ & $57.67(3.5)$ & 6 & $122.6(46.7)$ & $107.8(33.0)$ & $100.8(28.3)$ & 4 \\
\hline & \multicolumn{4}{|c|}{ Moderate + severe food insecurity $(n=63)$} & \multicolumn{4}{|c|}{ Moderate + severe food insecurity $(n=75)$} \\
\hline Energy (kcal/day) & $828(53)$ & 817 (35.52) & 828 (39) & 3 & $994(43)$ & $979(29)$ & $995(30)$ & 4 \\
\hline Carbohydrates (g/day) & $133(8.8)$ & $132(5.9)$ & $134(6.6)$ & 4 & $151(7.2)$ & $148(4.7)$ & $152(4.9)$ & 3 \\
\hline Protein (g/day) & $30(2.7)$ & $28(1.7)$ & $30(1.8)$ & 3 & $36(1.4)$ & $35(1.4)$ & $36(1.5)$ & 5 \\
\hline Lipids (g/day) & $20(1.4)$ & $20(1.0)$ & $21(1.0)$ & 4 & $24(1.4)$ & $28(1.0)$ & $26(0.6)$ & 3 \\
\hline Calcium (mg/day) & $560.9(53.1)$ & $550.19(38.5)$ & $561.0(43.1)$ & 2 & $589.7(38.5)$ & $588.6(59.1)$ & $562.1(25.7)$ & 1 \\
\hline Iron (mg/day) & $5.8(0.5)$ & $5.8(0.3)$ & $5.9(0.4)$ & 3 & $6.7(0.4)$ & $7.4(0.8)$ & $6.7(0.3)$ & 3 \\
\hline Vitamin C (mg/day) & $69.92(22.8)$ & $58.17(11.7)$ & $53.2(4.0)$ & 5 & 143.7 (87.9) & $115.4(39.5)$ & $383.1(160.2)$ & 4 \\
\hline
\end{tabular}


insecurity (Table 3). Hypothesis tests on the differences between the means were applied, and no statistically significant result related to the energy and all macro and micro nutrients analyzed was found.

The distribution of the de-attenuated mean tends to have a different sharp from the crude data ones mainly when the within-subject variance coefficients are high. For example, the energy means distributions by age and food insecurity groups showed more different sharps in both age groups with moderate to severe food security compared to food security group (Figure 2).

The number of required replications of 24hour recalls was estimated based on the expected correlation coefficients between the observed and real intakes being equal to 0.9 and in the variance ratio. In general, the results showed that l- to 3-day 24-hour recalls would be required to estimate the energy and nutrient intakes for these children. However, specific macronutrients (like protein and total fat) require more replication days ( 4 to 5 ) in the more vulnerable group for food insecurity. In addition, micronutrients like vitamin $\mathrm{C}$ had the highest estimated numbers of replication days in the young group (5 to 6 days) (Table 3).

\section{Discussion}

Measuring an individual's true food intake is difficult, and it is sometimes a challenge due to measurement and random errors in dietary assessment 4,6 . Research that aims to examine the associations between disease outcomes and dietary intakes requires accurate methods to estimate usual nutrient intakes in the early stage of life. For that purpose, information and implications about sources of within-subject variability in nutrient intakes in infants and very young children are very important.

For this study, age and socioeconomic markers were evaluated as potential factors of variability for energy and nutrient intakes, food insecurity groups were considered as a proxy of socioeconomic markers. Gender was not included as a source of variability, as a previous analysis showed no association between gender and dietary intake in this sample ${ }^{30}$. Results from other studies in the same age group have also corroborated this assumption 8,12 .

Food insecurity scales have been used to investigate socioeconomic characteristics 31 and have been strongly and inversely associated with the household income and food intake of the studied children $32,33,34$. The EBIA was adapted and validated based on the HFSSM 25,26,27,28,29. In the sample studied, Salles-Costa et al. 23 observed a significant and inverse association between socioeconomic indicators and food insecurity. Family income was the variable that discriminated both food security and insecurity; these results supported the use of food insecurity level estimated by EBIA as a proxy for a socioeconomic marker in our analyses.

Similar to the variance ratio results observed in our study, Laningan et al. 12 also identified variance ratio coefficients that were generally $<1$ among children of the same age in London. The number of days required for reliable dietary assessment is based on the ratio of within- to between-subject variability. Our data indicated that for children aged between 6 and 30 months, the between-subject variability was greater than within-subject variability. Therefore, the estimated number of days was lower than that required for the older age group; similar results have been obtained in earlier studies 8,35.

This effect may be due to the lack of extreme variability in infant diets, which are based on fewer foods than are consumed in adulthood 12 . During the first two years of life, infants move from frequent intake of a single food to a more adult diet, with similar meal and snack patterns 36 that involve increasing the numbers of foods of various forms (liquid or solid) and nutrient compositions 37 . In a study by Huybrechts et al. 6 , the variance ratio coefficients were lower among younger children $(<4$ years) than older children ( $>4$ years) for energy, macronutrient, calcium, iron and vitamin $\mathrm{C}$ among pre-school children from Belgium.

In relation to food insecurity and variability in food intake, a significant difference in food group intake has been observed among older children with moderate to severe food insecurity (vulnerable socioeconomic group) compared to the food security group. The first group showed low intakes of cereals, fruits, fats and protein (Figure 1c). This is one important factor that could account for variability and in the high number of days required to obtain $r \geq 0.9$ for energy and most nutrients in this group.

According to Nelson et al. 8, a high value of $r$ indicates a high proportion of subjects correctly classified and low proportion of misclassified individuals. If the variances ratio is low, fewer days of observation are required to classify subjects correctly with a high precision.

Micronutrients tend to be concentrated in certain foods. Thus, intakes can be very low or very high, depending on food choices per day ${ }^{3}$. This assumption may explain the high number of 24-hour recall replications required to estimate reliable vitamin $\mathrm{C}$ intake in this sample. The main 
Figure 2

Energy means distribution of children by age and food insecurity. Duque de Caxias, Rio de Janeiro, Brazil, 2005.

2a) Children 6-17 months old - food security + mild food insecurity

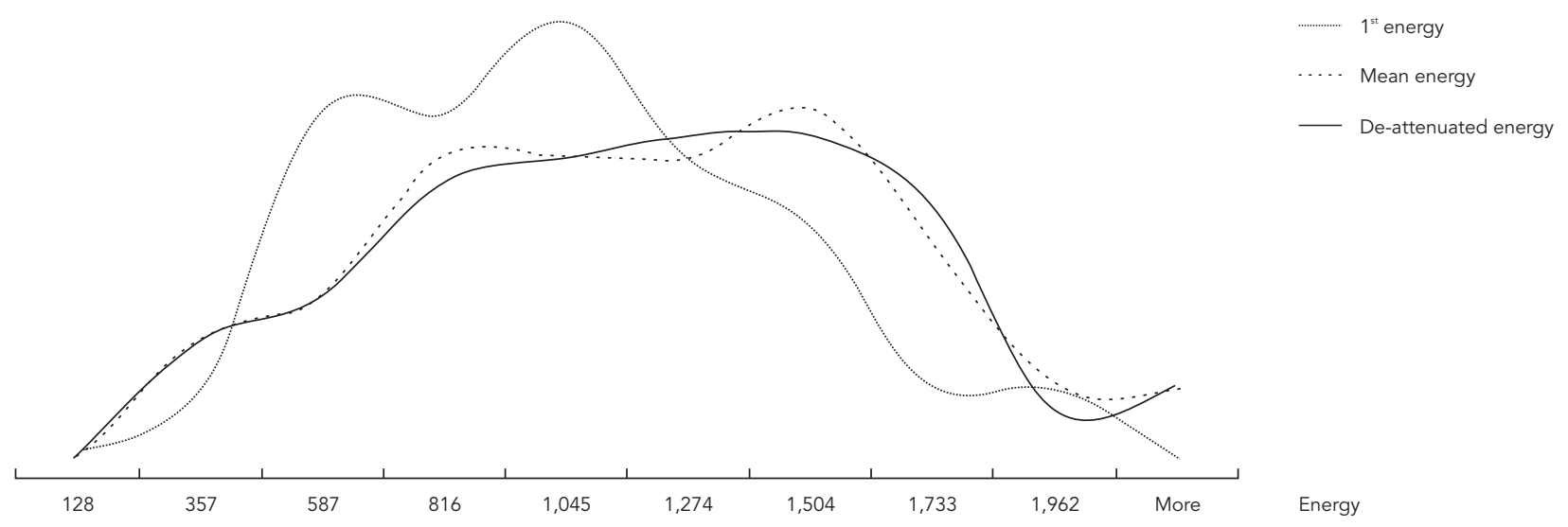

2b) Children 6-17 months old - moderate + severe food insecurity

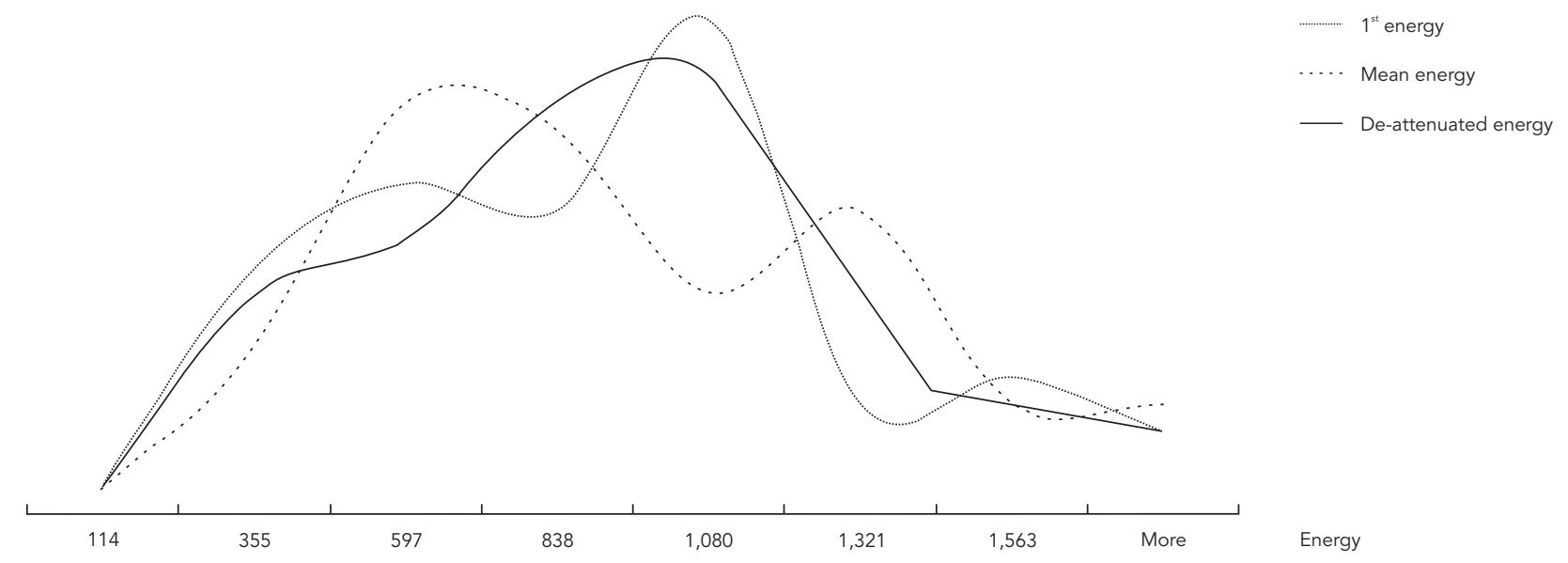

(continues)

food source for this nutrient for children less than 3 years old living in the studied area is fruit (Figure 1a), especially for the youngest group with food security, as presented in Figure 1b. Fruit intake is not usual among children with food insecurity, low income and without extensive food preservation ${ }^{38}$. In Duque de Caxias some families live in rural areas or grow one typical tropical fruit that is Barbados cherry (acerola) in their garden. The juice of this fruit is an important source of vitamin $\mathrm{C}$, as it contains more than orange juice (TACO). Thus, eventual or episodic consumption of a specific food, in this case, might overestimate the vitamin $\mathrm{C}$ intake and increase the withinsubject variability and the number of replication days required for this micronutrient. Janhs et al. 9 observed similar results when comparing the vitamin C intakes of Russian and U.S. children.

Calcium intake was another exception. The lowest number of 24-hour recall replications was 


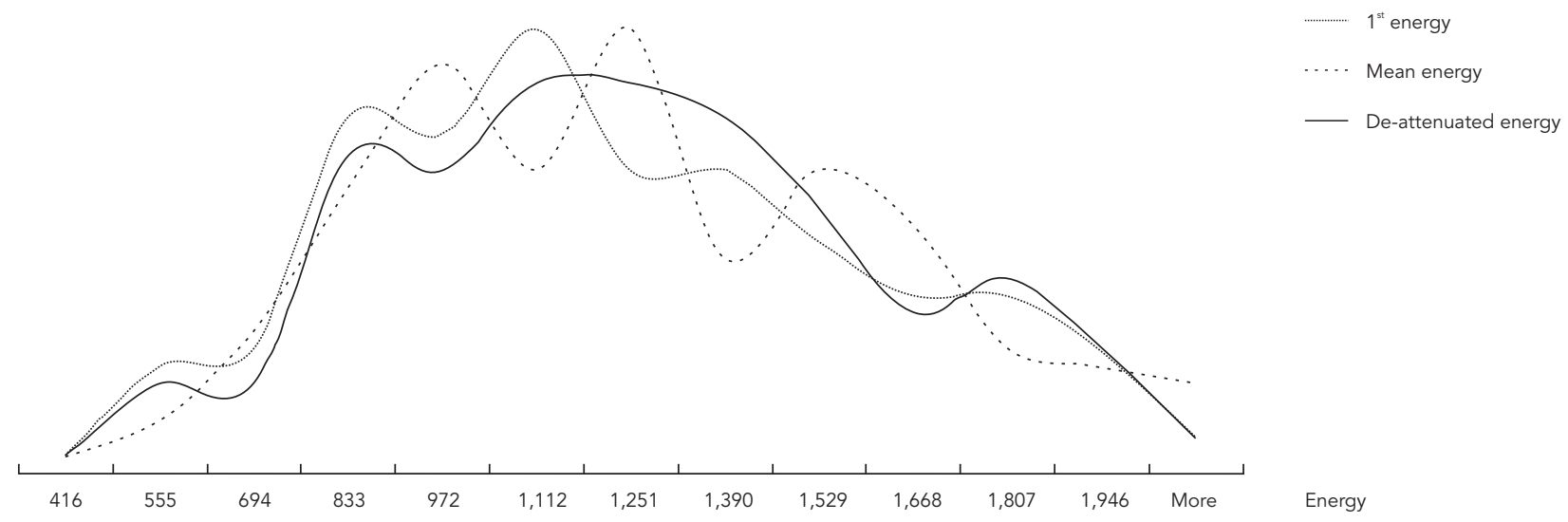

2b) Children 6-17 months old - moderate + severe food insecurity

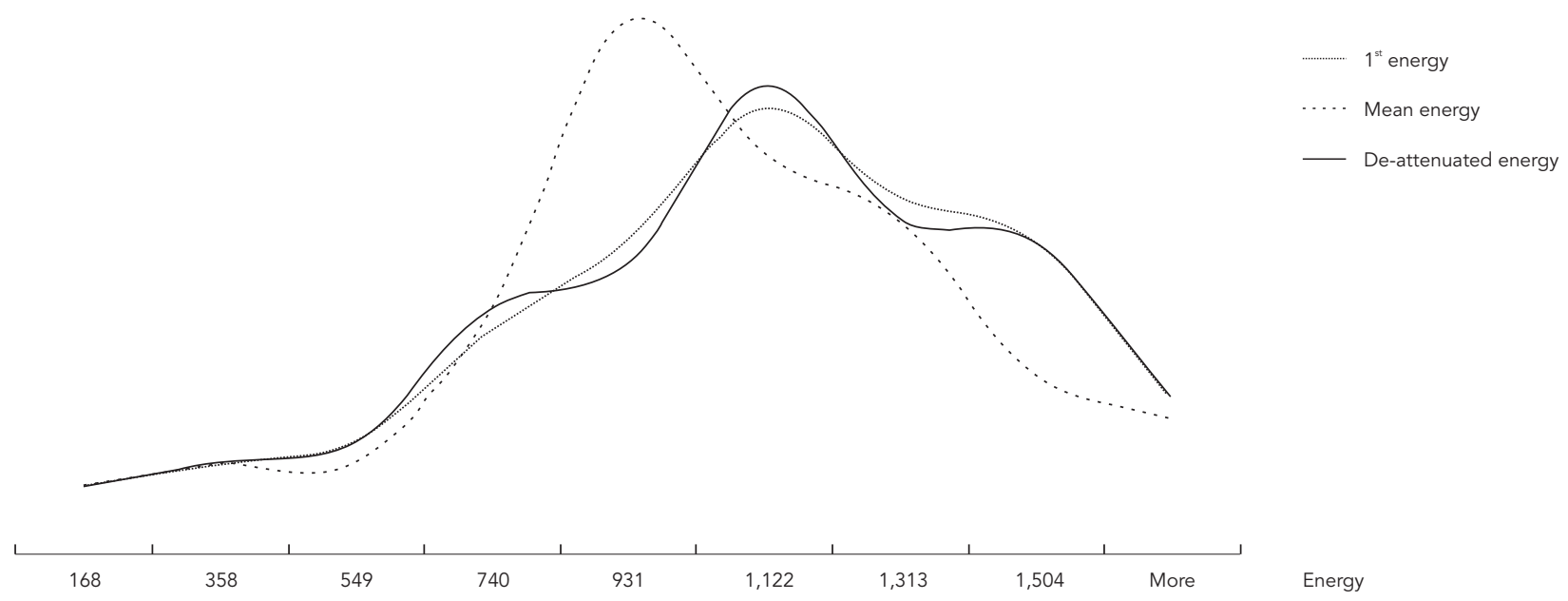

estimated for this micronutrient (1- or 2-day). This is understandable as the main food sources of this nutrient are milk and dairy foods, which are regular and predominant features of childhood diets, resulting in low within-sample variability 12 .

The study area in Duque de Caxias was a metropolitan area of Rio de Janeiro with a high proportion of families below poverty level and families with low income ${ }^{39}$ and this area has limited access to industrialized products (few numbers of supermarkets are available); these factors might contribute to the low variance ratio.
As the sampling design effect was not considered in the analysis of children's food intake this would attenuate the statistical significance of mean estimates, but since we did not find any statistically significant results, and also the coefficients of variance ratios are low, this is unlikely to effect our study. Besides, the method developed at Iowa State University for estimating usual nutrient intake distribution adds an adjustment term to make the adjusted mean match the mean on the original scale (Box-Cox transformation), therefore the de-attenuated mean is 
similar to the raw one, with low standard error of the mean 40,41 .

On the other hand, data on food intake was obtained for non-consecutive days and included a weekend day, avoiding the day of the week effect and the misleading correlations associated with consecutive days of dietary assessment 3 . This study showed the age and socioeconomic variables as important factors that could influence the variability of dietary intake in children, even when the within-subject variability does not present such a great magnitude as observed in other age groups (e.g., adolescents, adults). It is noteworthy that these sources of variability are more evident in the vulnerable socioeconomic group as identified by the food insecurity scale. In addition, the variability in macro- and micronutrient intakes was greater than the variance in the intake of energy; this was mainly true for micronutrients that are concentrated in a few food items, like vitamin C. Therefore, the number of 24-hour recall replications required to estimate the usual intake in this age group is low. However, a greater number of days will be required among low income groups and for vitamin $\mathrm{C}$ to mitigate random errors from these sources that might attenuate epidemiological risk estimates in any disease outcome related to the dietary intake of children in this population.

\section{Resumo}

Este artigo tem como objetivo descrever e analisar fontes de variação do consumo dietético de crianças na faixa etária de 6 a 30 meses de idade, obtidas por meio de dois recordatórios de 24 horas, aplicados em uma amostra de 383 crianças de ambos os sexos da Região Metropolitana do Rio de Janeiro, Brasil. Além da idade utilizou-se a escala de insegurança alimentar como proxy para caracterizar diferenças socioeconômicas. A análise baseou-se em grupos de alimentos, calculou-se a razão dos coeficientes de variação, sendo estimadas as médias brutas e deatenuadas para energia, macro e micronutrientes, e o número de repetições de recordatórios de 24 horas. Idade e insegurança alimentar influenciaram significantemente a média das porções dos grupos de alimentos. A razão dos coeficientes de variação para a maioria dos nutrientes foi menor que 1 , "exceto para vitamina $C$ no grupo de crianças na faixa etária mais jovem". O número de recordatórios necessários variou de um a seis dias, sendo maiores para vitamina $C$.

Consumo de Alimentos; Inquéritos sobre Dietas; Criança

\section{Contributors}

R. Salles-Costa participated in the overall study concept and the design of the study, supervising data collection, statistical analysis and manuscript writing and revising. G. S. Barroso was responsible for the PC-Side statistical analysis. M. A. Mello collaborated on the interpretation of PC-Side statistical analysis. M. M. L. Antunes participated in the analysis and interpretation of food intake. E. M. Yokoo participated in the manuscript concept, statistical analysis and manuscript writing and revising.

\section{Acknowledgments}

The authors thank Dr. Rosely Sichieri for her support, conception and coordination on the study design as well as her suggestions for this manuscript. This study was supported by the National Research Council (CNPq; Grant CT-Agronegócio MCT/CNPq/MDS-2003, no. 503139/2003-3). 


\section{References}

1. Livingstone MBE, Robson PJ, Wallace JM. Issues in dietary intake assessment of children and adolescents. Br J Nutr 2004; 92 Suppl 2:S213-22.

2. Willett W. Nutritional epidemiology. 2nd Ed. New York: Oxford University Press; 1998.

3. Beaton GH, Milner J, McGuire V, Feather TE, Little JA. Source of variance in 24-hour dietary recall data: implications for nutrition study design and interpretation. Carbohydrate sources, vitamins, and minerals. Am J Clin Nutr 1983; 37:986-95.

4. Palaniappan U, Cue RI, Paeyette H, Gray-Donald K. Implications of day-to-day variability on measurements of usual food and nutrient intakes. J Nutr 2003; 133:232-5.

5. Beaton GH. Approaches to analysis of dietary data: relationship between planned analyses and choice of methodology. Am J Clin Nutr 1994; 59(1 Suppl):253S-61S.

6. Huybrechts I, De Bacquer D, Cox B, Temme EH, Van Oyen H, De Backer G, et al. Variation in energy and nutrient intakes among pre-school children: implications for study design. Eur J Public Health 2008; 18:509-16.

7. Baranowski T, Domel SB. A cognitive model of children's reporting of food intake. Am J Clin Nutr 1994; 59(1 Suppl):212S-7S.

8. Nelson M, Black AE, Morris JA, Cole TJ. Betweenand within-subject variation in nutrient intake from infancy to old age: estimating the number of days required to rank dietary intakes with desired precision. Am J Clin Nutr 1989; 50:155-67.

9. Jahns L, Carriquiry A, Arab L, Mroz TA, Popkin BM. Whithin- and between-person variation in nutrient intakes of Russian and U.S. children differs by sex an age. J Nutr 2004; 134:3114-20.

10. Neuhaus JM, Murphy SP, Davis MA. Age and sex difference in variation of nutrient intakes among U.S. adults. Epidemiology 1991; 2:447-50.

11. Ogawa K, Tsubono Y, Nishino Y, Watanabe Y, Ohkubo T, Watanabe T, et al. Dietary sources of nutrient consumption in a rural Japanese population. J Epidemiol 2002; 12:1-8.

12. Lanigan JA, Wells JCK, Lawson MS, Cole TJ, Lucas A. Number of days needed to assess energy and nutrient intake in infants and Young children between 6 months and 2 years of age. Eur J Clin Nutr 2004; 58:745-50.

13. Wolf A, Yngve A, Elmadfa I, Poortvliet E, Ehrenblad B, Pérez-Rodrigo C, et al. Fruit and vegetable intake of mothers of 11-year-old children in nine European countries: The Pro Children Cross-sectional Survey. Ann Nutr Metab 2005; 49:246-54.

14. Spinelli MGN, Goulart RMM, Santos ALP, Gumiero LDC, Farhud CC, Freitas EB, et al. Consumo alimentar de crianças de 6 a 18 meses em creches. Rev Nutr 2003; 16:409-14.

15. Castro TJ, Novaes JF, Silva MR, Costa NMB, Francheschini SCC, Tinoco ALD, et al. Caracterização do consumo alimentar, ambiente socioeconômico e estado nutricional de pré-escolares de creches municipais. Rev Nutr 2005; 18:321-30.
16. Tuma RCFB, Costa THM, Schmitz BAS. Avaliação antropométrica e dietética de pré-escolares em três creches de Brasília, Distrito Federal. Rev Bras Saúde Matern Infant 2005; 5:419-28.

17. Barbosa RMS, Carvalho CGN, Franco VC, SallesCosta R, Soares EA. Avaliação do consumo alimentar de crianças pertencentes a uma creche filantrópica na Ilha de Paquetá, Rio de Janeiro, Brasil. Rev Bras Saúde Matern Infant 2006; 6:127-34.

18. Borges CQ, Silva RCR, Assis AMO, Pinto EJ, Fiaccone RL, Pinheiro SMC. Fatores associados à anemia em crianças e adolescentes de escolas públicas de Salvador, Bahia, Brasil. Cad Saúde Pública 2009; 25:877-88

19. Micheli ET, Rosa AA. Estimation of sodium intake by urinary excretion and dietary records in children and adolescents from Porto Alegre, Brazil: a comparison of two methods. Nutr Res 2003; 23:1477-87.

20. Assis AMO, Barreto ML, Gomes GSS, Prado MS, Santos NS, Santos LMP, et al. Childhood anemia prevalence and associated factors in Salvador, Bahia, Brazil. Cad Saúde Pública 2004; 20:1633-41.

21. Colucci ACAA, Philippi ST, Slater B. Desenvolvimento de um questionário de freqüência alimentar para avaliação do consumo alimentar de crianças de 2 a 5 anos de idade. Rev Bras Epidemiol 2004; 7:393-401.

22. Oliveira LPM, Assis AMO, Pinheiro SMC, Prado MS, Barreto ML. Alimentação complementar nos primeiros dois anos de vida. Rev Nutr 2005; 18:459-69.

23. Salles-Costa R, Pereira RA, Vasconcellos MTL, Veiga GV, Marins VMR, Jardim BC, et al. Associação entre fatores socioeconômicos e insegurança alimentar: estudo de base populacional na Região Metropolitana do Rio de Janeiro, Brasil. Rev Nutr 2008; 21:99-109.

24. Pérez-Escamilla R, Segall-Corrêa AM, Kurdian Maranha L, Sampaio MMF, Marín-León L, Panigassi G. An adapted version of the U.S. Department of Agriculture Food Insecurity module is a valid tool for assessing household food insecurity in Campinas, Brazil. J Nutr 2004; 134:1923-8.

25. Instituto Brasileiro de Geografia e Estatística. Estudo Nacional de Despesas Familiares: 1974-1975. Rio de Janeiro: Instituto Brasileiro de Geografia e Estatística; 1977.

26. Secretaria de Políticas de Saúde, Ministério da Saúde/Organização Pan-Americana da Saúde. Guia alimentar para crianças menores de dois anos. Brasília: Ministério da Saúde; 2002. (Série A. Normas e Manuais Técnicos).

27. Philippi ST, Cruz ATR, Colucci ACA. Pirâmide alimentar para crianças de 2 a 3 anos. Rev Nutr 2003; 16:5-19.

28. Pérez-Escamilla R, Segall-Corrêa AM. Food insecurity measurement and indicators. Rev Nutr 2008; 21 Suppl:15s-26s. 
29. Melgar-Quiñonez HR, Nord M, Pérez-Escamilla R, Segall-Corrêa AM. Psychometric properties of a modified US-household food security survey module in Campinas, Brazil. Eur J Clin Nutr 2008; 62:665-73.

30. Antunes MML. Insegurança alimentar e consumo dietético de crianças menores de 30 meses residentes em Duque de Caxias [Dissertação de Mestrado]. Rio de Janeiro: Instituto de Nutrição Josué de Castro, Universidade Federal do Rio de Janeiro; 2008.

31. Ziegler J. Economic, social and cultural rights: the right to food. http://www.righttofood.org/new/ PDF/ECN4200410.pdf (accessed on 22/Jul/2009).

32. Kaiser LL, Melgar-Quiñonez HR, Lamp CL, Johns MC, Sutherlin JM, Harwood JO. Food security and nutricional outcomes of preschool-age Mexican-American children. J Am Diet Assoc 2002; 102:924-9

33. Kaiser LL, Melgar-Quiñonez HR, Townsend MS, Nicholson Y, Fujii ML, Martin AC, et al. Food insecurity and food supplies in Latino households with young children. J Nutr Educ Behav 2003; 35:148-53.

34. Matheson DM, Varady J, Varady A, Killen JD. Household food security and nutritional status of Hispanic children in the fifth grade. Am J Clin Nutr 2002; 76:210-7.
35. Black AE, Cole TJ, Wiles SJ, White F. Daily variation in food intake of infants from 2 to 18 months. Hum Nutr Appl Nutr 1983; 37:448-58

36. Skinner JD, Ziegler P, Pac S, Devaney B. Meal and snack patterns of infants and toddlers. J Am Diet Assoc 2004; 104(1 Suppl 1):s65-70.

37. Fisher JO, Butte NF, Mendoza PM, Wilson TA, Hodges EA, Reidy KC, et al. Overestimation of infant and toddler energy intake by 24 -h recall compared with weighed food records. Am J Clin Nutr 2008; 88:407-15

38. Lorson BA, Mergar-Quiñonez HR, Taylor CA. Correlates of fruit and vegetable intakes in US children. J Am Diet Assoc 2009; 109:474-8.

39. Pimentel PG, Sichieri R, Salles-Costa R. Insegurança alimentar, condições socioeconômicas e indicadores antropométricos em crianças da Região Metropolitana do Rio de Janeiro/Brasil. Rev Bras Estud Popul 2009; 26:283-94.

40. Nusser SM, Carriquiry AL, Dodd KW, Fuller WA. A semi-parametric transformation approach to estimating usual intake distributions. J Am Stat Assoc 1996; 91:1440-9.

41. Tooze JA, Midthume D, Dodd K, Freedman LS, Krebs-Smith SM, Subbar AF, et al. A new statistical method for estimating the usual intake of episodically consumed foods with application to their distribution. J Am Diet Assoc 2006; 106:1575-87.

Submitted on 24/Sep/2009

Final version resubmitted on 23/Dec/2009

Approved on 27/Feb/2010 